\title{
Brand Loyalty at Chain Hotel in Denpasar
}

\section{Made Bayu Wisnawa, I Made Antara and I Komang Gede Bendesa}

\author{
Doctorate Program in Tourism \\ Universitas Udayana
}

Corresponding author: bayu.wisnawa@triatma-mapindo.ac.id

\begin{abstract}
ARTICLE INFO
ABSTRACT

Received

20 January 2018

Accepted

12 March 2018

Available online

30 March 2018

Purposes of this research are: (i) to find out the influence of brand image toward customer satisfaction (ii) to find out the influence of customer satisfaction toward brand loyalty (iii) to find out the influence of brand image toward brand loyalty and (iv) to find out the role of customer satisfaction as a mediating variable between brand image and brand loyalty. Structural Equation Modelling (SEM) was developed to answer the research problems. The number of respondent was 150 which was collected through offline and online self-administered questionnaire. There were 13 indicators used to measure each construct. The results show that (i) brand image positively and significanly influence customer satisfaction, (ii) customer satisfaction positively and significantly influenced brand loyalty, (iii) brand image did not influence brand loyalty, and (iv) customer satisfaction did not mediate the relationship between brand image toward brand loyalty.
\end{abstract}

Keywords : brand image, customer satisfaction, brand loyalty

\section{Introduction}

\section{Background}

Hotel is an accomodation facility that plays important role in tourism. Without it, tourists will experience difficulty in enjoying their vacation. At the hotel, tourists might stay up to 24 hours per day, therefore, accomodation service and food and beverage service should be available with quality service that is able to meet the needs and desires of tourists. Hotel is also a place for tourists to be able to neutralize all the inconveniences gained during the vacation. It might be possible that all of the complaints that tourists get during the vacation will be reduced if they get a satisfactory service from the hotel (Lo, 2010). Therefore, a hotel also has an important role in maintaining and improving the image of tourist destinations.
Bali as an international tourist destination requires the availability of quality hotels. Tourist growth that tends to increase over the last decade after the $2^{\text {nd }}$ Bali Bomb incident has prompted investors' intention to invest in the hospitality business sector. As the result, the growth of hotels and accommodation facilities in Bali, especially in the southern regions of Bali (Badung Regency and Denpasar City) is increasing. Moreover, the investors are not only aiming to develop the hospitality business, but also more likely in the property business.

The growth rate of hotels that exceed the growth rate of tourists visitation to Bali causes a tight competition for hotel businesses. The competition is not only head to head, but it is already beyond the limit of reasonableness. Star hotels do not only compete among the same star hotels class, but also compete among different star hotels 
classes, and even the non star hotels. This is worsen by the development of online marketing system that offers a wide range of ease, choice and even a loyalty program that attracts tourists.

Table 1. Occupancy Rate of Star-rated Hotels Room in Bali 2012 to 2016

\begin{tabular}{cccccc}
\hline \multirow{2}{*}{ No } & \multirow{2}{*}{$\begin{array}{c}\text { Ye } \\
\text { ar }\end{array}$} & \multicolumn{5}{c}{$\begin{array}{c}\text { Five } \\
\text { Stars }\end{array}$} & $\begin{array}{c}\text { Four } \\
\text { Stars }\end{array}$ & $\begin{array}{c}\text { Three } \\
\text { Stars }\end{array}$ & $\begin{array}{c}\text { All Stars } \\
\text { Hotels }\end{array}$ \\
\hline \multirow{2}{*}{1} & $\begin{array}{r}20 \\
12\end{array}$ & 64.13 & 63.21 & 62.07 & 62.25 \\
\hline 2 & $\begin{array}{r}20 \\
13\end{array}$ & 61.91 & 60.68 & 58.59 & 59.85 \\
\hline 3 & $\begin{array}{r}20 \\
14\end{array}$ & 61.46 & 61.83 & 58.67 & 60.31 \\
\hline 4 & $\begin{array}{r}20 \\
15\end{array}$ & 62.95 & 62.37 & 55.12 & 60.48 \\
\hline 5 & $\begin{array}{r}20 \\
16\end{array}$ & 64.38 & 66.54 & 55.13 & 61.86 \\
\hline Average & 62.97 & 62.92 & 57.92 & 60.95 \\
\hline \multicolumn{6}{c}{}
\end{tabular}

Source: Bali Central Bureau of Statistics, 2017

The Table 1 illustrates the condition of the star hotels competition. This competition causes the occupancy rate of star hotels' room to decrease in 2012 by $62.25 \%$ to $59.85 \%$ in 2013. Then it increased until 2016, but it was not able to reach figures such as in 2012. Currently, hotels and accommodation facilities are not only located around main streets, but have entered the residential area of Denpasar City.

In general, to strengthen the position of competition in accommodation services, some hotels join in a management group which is often called as chain hotel. This efforts tend to maintain market, save marketing costs and ease in the market penetration. There are quite a number of chain hotels in Denpasar, such as Amaris, Haris, Golden Tulip, Puri Saron, Inna, and Pop. Those chain hotels have their own uniqueness and different market segments. Chain hotels in Denpasar have a higher ability to compete than the individual hotel.

Inna Group Hotel in Denpasar City, which consists of Inna Bali Heritage Hotel, Inna Grand Bali Beach Hotel, and Inna Sindhu

http://ojs.unud.ac.id/index.php/eot
Beach Hotel, also experienced pressure due to the competition. This can be seen from the occupancy rate of rooms in the range of $50.00 \%$ to $60.00 \%$ in the period of 2012 to 2016. When this condition is if left unchecked, then it will certainly affect the development of this government-run company. The circumstances described above illustrate the increase of the intense competition level faced by the Inna Group Hotel in Denpasar. Inna hotel manager has to make improvements in hotel management. There are many things that can be done to survive in the very tight competitive situation. One of the strategic efforts is to realize customer loyalty through brand (brand loyalty).

Brand loyalty is a condition in which the customers (in this case are tourists or guests) who stay at the hotel have (i) a good knowledge on the products offered by the hotel, (ii) good experiences that affect the emotions / feelings of the customers, (iii) a tendency to stay at the hotel on any occasion, and (iv) made product purchases (staying), recomended to their colleagues to stay at the hotel and even defended the hotel if there is a negative perception about the hotel.

Brand loyalty is a multi-dimensional concept. The main constructs in shaping brand loyalty are brand image and customer satisfaction. Nevertheless there are many other dimensions that construct brand loyalty, such as switching cost, switching behavior, investment size, brand awareness and others. Theoretically, the study on brand loyalty still needs to be developed, since among the researchers, there is still no agreement reached related to the concept of brand loyalty (Suhartanto, 2011). Empirically, the high level of competition has lowered brand loyalty at Inna Group Hotel in Denpasar. This can be seen from the level of the hotel occupancy which is below the standard and the stagnant growth of the repeater guests which tend to decline over the last five years. This condition cannot be separated from the behavior of tourists who tend to try new competitor hotels that offer loyalty program which attracts customers.

Brand image has an important role in shaping customer loyalty toward the brand. A unique and good brand image will have its 
own value in the minds of customers. The hotel industry is in need of a brand image (Wu, 2014), in which the service element, which is a distinguishable competition element, is considered as almost identical in terms of performance, price, and availability. Unfortunately, most of the brand image researches are done on manufactured products, and in the retail context, and very few in service firms especially in the hospitality sector. Empirically, the brand image of the Inna Group Hotel is generally identical to a cheap brand, strategic location, standard facilities and tends to have an old hotel image. Therefore, expanding the brand loyalty model by including brand image in the service context is a must. The inclusion of brand image into brand loyalty does not only increase model prediction power (Kotler, Bowen and Makens, 2010), but it also provides a better understanding on the factors that motivate guest loyalty in the hospitality industry (Wisnawa, 2011).

Customer satisfaction is a condition in which there is a similarity or an excess between perceived service and expected service (Oliver, 1980; Gundersen, Heide and Olsson, 1996). Satisfied customers will tend to be loyal. In addition, customer satisfaction will strengthen the prediction of brand loyalty model (McQuitty, Finn and Wiley, 2000). Empirically, the customer satisfaction at Inna Group Hotel in Denpasar are vary, some are satisfied, some are not. Based on the documentation results on Trip Advisor website, customer satisfaction is achieved through the friendly service, the strategic location and the competitive price. Dissatisfaction of the customers is mostly due to the condition of the hotel's facilities that are outdated and dusty. In addition, the old equipments often cause operational problems, for example is the inability of the hotel to provide hot water for bathing for 24 hours.

\section{Research Objectives}

Purposes of this research are:

1. To find out the influence of brand image and customer satisfaction at Inna Group Hotel in Denpasar City.

2. To find out the influence of customer satisfaction and loyalty at Inna Group Hotel in Denpasar City.
3. To find out the influence of brand image and brand loyalty at Inna Group Hotel in Denpasar City.

4. To find out the role of customer satisfaction in mediating the relationship between brand image and brand loyalty at Inna Group Hotel in Denpasar City.

\section{Literature Review}

Researches on brand loyalty are still being developed to date. This is because there is no agreement from academicians on the concept of brand loyalty. Some groups see loyalty from a behavioral point of view, others see loyalty from the standpoint of attitude, (Pedersen and Nysveen, 2001). Furthermore, there are those that combine attitude and behavior which is also called as composite point of view. Anyone who sees brand loyalty as a multi-dimensional model that combines the customer's inner dimensions (cognitive, affective, conative and behavioral) (Back and Parks, 2003), and from the outside of the customer's dimensions in form of hotel management efforts to achieve customer loyalty, such as: service quality, brand image, brand awareness, customer satisfaction, perceived value, perceived risk, quality alternative, investment size, etc. Other researcher Mahasuweerachai (2012) conducted a study on the relationship between service quality, brand extensions, brand reputation, perceived image, perceived risk in forming brand loyalty in star hotels in the United States. The findings of the study indicated that there was a positive and significant influence of all those variables toward brand loyalty. The higher the reputation, the image, the quality of service in a hotel brand, then the higher the customer loyalty. However, the above study is inconsistent with research by Noor (2014) and Shahroudi and Naimi (2014) where the brand image had no real influence on brand loyalty. The differences of the results of those previous researches show that it is necessary to do further research on both variables.

\section{Hypotheses}

Based on the above description, the hypothesis of the research are as follows: 
1. Brand image has a positive and significant influence to customer satisfaction at Inna Group Hotel in Denpasar City.

2. Customer satisfaction has a positive and significant influence to brand loyalty at Inna Group Hotel in Denpasar City.

3. Brand image has a positive and significant influence to brand loyalty at Inna Group Hotel in Denpasar City.

4. Customer satisfaction mediates the relationship between brand image and brand loyalty at Inna Group Hotel in Denpasar City

\section{Methodology}

This research is a quantitative research using Structural Equation Modelling (SEM) with the help of AMOS 22.0 computer program. The samples used were 150 respondents using purposive sampling method, in which the respondent had stayed at least once at the hotel. The samples were eligible, because the requirement of SEM analysis with maximum likelihood (ML) is at least 200 samples (Ferdinand and Manajemen, 2000; Hair, Robert and David, 2006; Ghozali, 2014). The were 13 indicators used, thus, the minimum sample was 5 times of the indicators that was 65 and above the maximum sample that was 10 times of the indicators that was 130. Technique of collecting data by using questionnaire which was distributed online and offline for three months from April to July 2017. The validity and reliability tests were performed before the questionnaire was distributed online, then it was followed by analysing data using SEM (Ghozali, 2014).

The phases of SEM analysis were as follows: (i) developing of the model based on the theory, (ii) developing path diagrams and structural equations., (iii) selecting the input matrix type and the proposed model estimation, (iv) assessing the structural model identification, (v) assessing the performance of goodness of fit, and (vi) interpreting and modifying the model.

\section{Results and Discussion}

This section describes the results of validity and reliability test, respondent profile, customers' behaviors in hotel, descriptive research variable, result of data analysis using
SEM, hypothesis testing, and then proceed with discussion of of the research results.

\section{Results of Validity and Reliability}

Before the questionnaire was distributed online and offline, the validity and reliability tests were tested first by 30 respondents. The test results showed that the instruments were valid with the correlation between items in the overall variables were above 0.3 . Instruments were declared valid if the alpha-cronbach value of each variable was above 0.6 as in Appendix 1 (validity and reliability tests results). Furthermore, the questionnaire was distributed online and offline. The offline's responrate was very low, out of the 200 distributed questionnaires, there was only $15 \%$ returned which was 30 questionnaires. There were 185 respondents who filled the questionnaire, but there were only 150 questionnaires which were answered fully and valid to be analyzed further.

\section{Characteristics of Respondents}

The respondents' profiles in this research were mostly (i) men (89\%), (ii) age in the range of 26 to 35 years old $(37.30 \%)$, (iii) originating from Indonesia $(48.70 \%)$, (iv) working as private employees $(32.00 \%)$, (v) having income > 25 million per month (29.30\%), (vi) spending 5 - 10 million during vacation (34.70\%), (vii) having a vacation purpose $(59.30 \%)$, (vii) staying for 1-3 nights $(53.30 \%)$, and (viii) it was the second stay (82.00\%).

\section{Results of SEM Analysis}

\section{Evaluation of Normality, Outlier, Multicolinearity and Singularity}

Output of Amos 22.0 shows that the critical values of kurtoisis of all indicators were in the range of \pm 2.58 which indicates that all of the data which were used in this research were normally distributed. Mahalanobis distance value compared to chisquare value with significance level of 0.001 , degree of freedom of 15 or $\chi^{2}$ (13: 0.001$)=$ 27.688 which indicates that there was no multivariate outlier in this research. Multicollinearity and singularity can be detected by the determinant of a covariant 
matrix which is equal to zero (Ghozali, 2014). The results show that the value of the covariance matrix was 0.001. Structural equation model can be seen in the figure below.

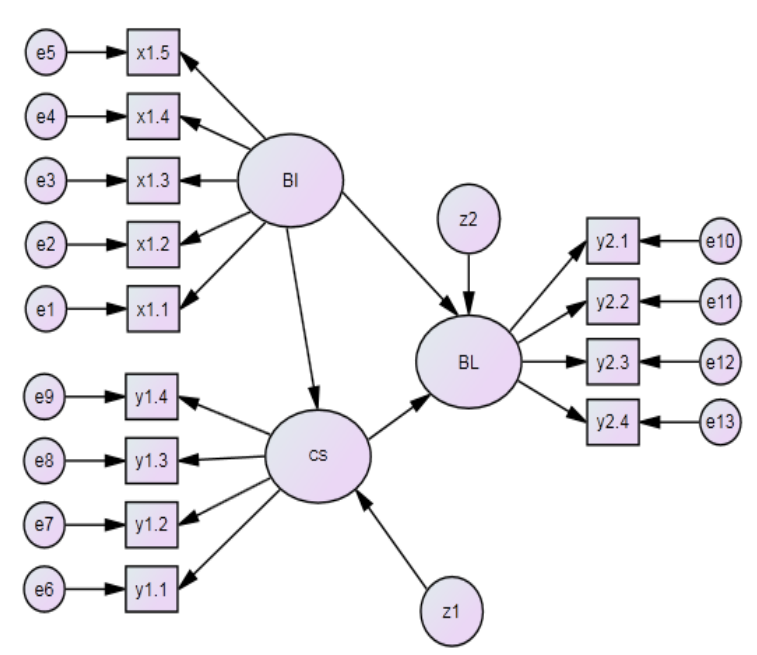

Figure 1. Structural Equation Model of Brand Loyalty at Chain Hotel in Denpasar

Results of the full model can be seen in Table 2. All of the rquirements for the fit model such as Chi-square $\chi^{2}$, GFI, AGFI, TLI, PNFI and PGF are fulfil the requirement of fit model meaning that the model is fit which indicates that developed confirmatory model of this reseacrh can be accepted which can explain relationship between variable used in this research.

Table 2. Goodness of Fit Index

\begin{tabular}{llccc}
\hline No & $\begin{array}{l}\text { Goodness } \\
\text { of Fit Index }\end{array}$ & $\begin{array}{c}\text { Cut of } \\
\text { Value }\end{array}$ & Result & Information \\
\hline 1 & $\begin{array}{l}\text { Chi-square } \\
\chi^{2}\end{array}$ & $\begin{array}{c}\text { Expected } \\
\text { to be } \\
\text { small }\end{array}$ & 46.681 & Good \\
\hline 2 & Significance & $\geq 0.05$ & 0.527 & Good \\
\hline 3 & GFI & $\geq 0.90$ & 0.955 & Good \\
\hline 4 & AGFI & $\geq 0.90$ & 0.914 & Good \\
\hline 5 & TLI & $\geq 0.95$ & 1.002 & Good \\
\hline 6 & PNFI & $0.60-$ & 0.591 & Good \\
\hline 7 & PGFI & 0.90 & & Good \\
\hline
\end{tabular}

Source : Result of Data Analysis, 2017

\section{Hypothesis testing}

Table 3. Parameter Estimation

\begin{tabular}{|l|c|c|c|c|c|c|}
\hline & Estimate & $\begin{array}{c}\text { Standardized } \\
\text { Regression } \\
\text { Weights }\end{array}$ & S.E. & C.R. & $\mathrm{P}$ & Label \\
\hline $\mathrm{CS}<-\mathrm{Bl}$ & 2.114 & .733 & .601 & 3.519 & $* * *$ & par 13 \\
$\mathrm{BL}<-\mathrm{Bl}$ & .276 & .121 & .265 & 1.042 & .297 & par 11 \\
$\mathrm{BL}<-\mathrm{CS}$ & .581 & .732 & .104 & 5.605 & $* * *$ & par 12 \\
$\mathrm{x} 1.1<-\mathrm{Bl}$ & 1.000 & .326 & & & & \\
$\mathrm{x} 1.2<-\mathrm{Bl}$ & 2.362 & .789 & .635 & 3.719 & $* * *$ & par 1 \\
$\mathrm{x} 1.3<-\mathrm{Bl}$ & 1.732 & .578 & .495 & 3.499 & $* * *$ & par 2 \\
$\mathrm{x} 1.4<-\mathrm{Bl}$ & 2.567 & .805 & .710 & 3.615 & $* * *$ & par 3 \\
$\mathrm{x} 1.5<-\mathrm{Bl}$ & 1.593 & .515 & .483 & 3.295 & $* * *$ & par 4 \\
$\mathrm{y} 1.1<-\mathrm{CS}$ & 1.000 & .846 & & & & \\
$\mathrm{y} 1.2<-\mathrm{CS}$ & 1.023 & .853 & .079 & 12.981 & $* * *$ & par 5 \\
$\mathrm{y} 1.3<-\mathrm{CS}$ & 1.023 & .850 & .078 & 13.106 & $* * *$ & par 6 \\
$\mathrm{y} 1.4<-\mathrm{CS}$ & 1.066 & .862 & .081 & 13.235 & $* * *$ & par 7 \\
$\mathrm{y} 2.1<-\mathrm{BL}$ & 1.000 & .722 & & & & \\
$\mathrm{y} 2.2<-\mathrm{BL}$ & 1.083 & .779 & .123 & 8.827 & $* * *$ & par 8 \\
$\mathrm{y} 2.3<-\mathrm{BL}$ & 1.102 & .826 & .114 & 9.639 & $* * *$ & par 9 \\
$\mathrm{y} 2.4<-\mathrm{BL}$ & 1.281 & .810 & .139 & 9.235 & $* * *$ & par 10 \\
\hline Source. Result ofDataAnalysis.2017
\end{tabular}

Source : Result of Data Analysis, 2017

The results show that the first hypothesis which says that brand image has a positive and significant influence toward customer satisfaction was proven by the significance value of 0.000 with direct influence value of 0.733 . This is in accordance with Suhartanto (2011) and Wisnawa (2011).

The second hypothesis, which says that customer satisfaction has a positive and significant influence toward brand loyalty was proven by the significance value of 0.000 with direct influence value of 0.732 . This research is in line with Suhartanto (2011); Kuo (2012); Johnson (2013); Timmerman (2013); AlMsallam (2015); Jraisat et al. (2015); Martínez (2015); Tabaku and Zerellari (2015).

The third hypothesis which says that brand image has a positive and significant influence toward brand loyalty was not proven by the significance value of 0.297 . This is not in accordance with the Suhartanto (2011) and Wisnawa (2011). This research supports the research results of Noor (2014) and Shahroudi and Naimi (2014) in which the brand image has no real influence toward brand loyalty. 
The fourth hypothesis which says that customer satisfaction mediates the relationship between brand image toward brand loyalty was not proven by using Sobel Test which showed that the t-count was 1.1901 which was smaller than t-table $(0.05: 150)=1.976$.

\section{Discussion}

Brand image has a positive and significant influence toward customer satisfaction. This indicates that the management of Inna Group Hotel in Denpasar should be able to create hotel's image as a comfortable place (with the highest loading factor $=0.805$ ) to improve customer satisfaction, thus, the customers will not regret in taking decision to stay at the hotel (highest loading factor $=0.862$ ). However, the managers still have to pay attention to the reputation of the hotel, and the luxury and uniqueness image of the hotel. By increasing brand image, customer satisfaction will surely increase. The effort of creating hotel's image as a comfortable place to stay can be done by improving the quality of service, especially on tangible aspects. The facilities of Inna Group Hotel in Denpasar, which are out of date will certainly disrupt the operational of the hotel. Similarly, the renovations of the building should not eliminate the uniqueness of the hotel as a historical hotel.

Customer satisfaction has a positive and significant influence toward brand loyalty, this means that if the customer satisfaction increases, then customer loyalty toward the brand will also increase. Thus, customers will prefer to stay at the hotel than to stay at other hotels. The hotel manager has to be able to convince the customers that their decision to stay at Inna Group Hotel in Denpasar is the right decision (highest loading factor $=0.862$ ). This can be done by giving a serious attention to the guest complaints. Every guest complaint should be responded to and handled as soon as possible. Similarly, customers' expectations must be met. If guests book a double room, it should be upon check-in that it is realized. Similarly, special guests' requests at check-in should also be met.

Statistically, brand image does not have a significant and positive influence toward http://ojs.unud.ac.id/index.php/eot brand loyalty. Nevertheless, the manager should still pay attention to the image of the hotel, because it will influence customer satisfaction because customer satisfaction will influence brand loyalty. This means that the brand image has an indirect influence toward the brand loyalty.

When the manager has considered all of the variables mentioned above, it is expected that customers will stay longer at the hotel, spend more money and be loyal to stay again on the next visit.

\section{Conclusion}

Brand image has a positive and significant influence toward customer satisfaction, in which customer satisfaction has a positive and significant influence toward brand loyalty but does not mediate the relationship between brand image and brand loyalty.

\section{Implications}

This research reinforces previous researches, which tested the influence of brand image and customer satisfaction toward brand loyalty, with the result that these two exogenous variables had a positive and real influence toward brand loyalty. Practically, this research is expected to give a thought contribution for accommodation entrepreneurs in making loyalty program by paying attention to the indicators of each variable used in this research.

\section{Suggestions for further research}

It is suggested that a hotel manager should pay attention to hotel's comfort in improving the image of the hotel (brand image), so that customers will feel satisfied and confident that the decision to stay at the hotel is the correct choice. Thus, the customers will recommend the hotel to their friends.

\section{Limitation}

This research is limited in testing the relationship of the variables that make up brand loyalty, which only uses brand image and customer satisfaction. Future research is expected to test using many more relationships 
with the addition of variable trust, switching cost, investment size which are more relevant to hotel's competition trend which is increasing tight nowadays. Similarly, future research should not only use star hotels as the object, but it should be more clustered, thus, the discussion between variables will be more specific and in accordance to customers' characteristics and hotels' characteristics.

\section{Reference}

Al-Msallam, S. (2015) 'Customer satisfaction and brand loyalty in the hotel industry', European Scientific Journal.

Back, K.-J. and Parks, S. C. (2003) 'A brand loyalty model involving cognitive, affective, and conative brand loyalty and customer satisfaction', Journal of Hospitality \& Tourism Research. Sage Publications Sage CA: Thousand Oaks, CA, 27(4), pp. 419-435.

Ferdinand, A. and Manajemen, S. E. M. D. P. (2000) 'Aplikasi model-model Rumit dalam Penelitian untuk Tesis S-2 dan Disertasi S-3', BP Universitas Diponegoro, Semarang.

Ghozali, I. (2014) Model persamaan struktural: Konsep dan aplikasi dengan program AMOS 22.0. Badan Penerbit Universitas Diponegoro.

Gundersen, M. G., Heide, M. and Olsson, U. H. (1996) 'Hotel guest satisfaction among business travelers: what are the important factors?', Cornell hotel and restaurant administration quarterly. Sage Publications Sage CA: Thousand Oaks, CA, 37(2), pp. 72-81.

Hair, J., Robert, B. and David, O. (2006) 'Marketing Research: Within a Changing Environment, revised international edition Ed'. New York: McGrawHill/Irwin.

Johnson, D. P. (2013) 'Attitudinal loyalty: A mixed method study of Apple fandom'. Capella University.
Jraisat, L. E. et al. (2015) 'Perceived brand salience and destination brand loyalty from international tourists' perspectives: the case of Dead Sea destination, Jordan', International Journal of Culture, Tourism and Hospitality Research. Emerald Group Publishing Limited, 9(3), pp. 292-315.

Kotler, P., Bowen, J. T. and Makens, J. C. (2010) Marketing for Hospitality and Tourism (Fifth Edition). New Jersey: Pearson Prentice Hall.

Kuo, H.-Y. (2012) 'Modelling the Influence of Green Brand Image on Brand Loyalty in Technology Products: Relationships Among Green Brand Image, Brand Identification, Perceived Value and Brand Loyalty'. Alliant International University, Alliant School of Management, San Diego.

Lo, K. P. (2010) 'Emotional design for hotel stay experiences: Research on guest emotions and design opportunities'. School of Design, The Hong Kong Polytechnic University.

Mahasuweerachai, P. (2012) A study of spillover effects of multiple hotel brand extensions. Oklahoma State University.

Martínez, P. (2015) 'Customer loyalty: exploring its antecedents from a green marketing perspective', International Journal of Contemporary Hospitality Management. Emerald Group Publishing Limited, 27(5), pp. 896-917.

McQuitty, S., Finn, A. and Wiley, J. B. (2000) 'Systematically varying consumer satisfaction and its implications for product choice', Academy of Marketing Science Review. Academy of Marketing Science Review, 2000, p. 1.

Noor, M. F. (2014) 'Pengaruh Brand Image dan Brand Trust Terhadap Brand Loyalty King Thai Tea Bandung', IMAGE, 3(2), p. 109. 
Oliver, R. L. (1980) 'A cognitive model of the antecedents and consequences of satisfaction decisions', Journal of marketing research. JSTOR, pp. 460469.

Shahroudi, K. and Naimi, S. S. (2014) 'The impact of brand image on customer satisfaction and loyalty intention (case study: consumer of hygiene products)', International Journal of Engineering Innovations and Research. International Journal of Engineering Innovations and Research (IJEIR), 3(1), p. 57.

Suhartanto, D. (2011) 'An examination of brand loyalty in the Indonesian hotel industry'. Lincoln University.

Tabaku, E. and Zerellari, M. (2015) 'Brand loyalty and loyalty programs; a literature review', Romanian Economic and Business Review. Romanian-American University, Scientific Research Department, 10(2), p. 87.

Timmerman, J. (2013) 'The relationship between hotel staff service delivery with customer attitudinal loyalty and financial outcomes'.

Wisnawa, I. M. B. (2011) 'ASPEK ASSURANCE TERHADAP KEPUASAN PELANGGAN DAN MINAT MENGINAP KEMBALI PADA HOTEL PAN PACIFIC NIRWANA BALI RESORT', Volume 2 No. 1 Tahun 2011, 2(1).

Wu, H.-C. (2014) 'The effects of customer satisfaction, perceived value, corporate image and service quality on behavioral intentions in gaming establishments', Asia Pacific Journal of Marketing and Logistics. Emerald Group Publishing Limited, 26(4), pp. 540-565. 